ROCZNIKI TEOLOGICZNE

Tom LXVIII, zeszyt $7-2021$

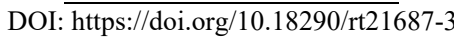

MARGRIET GOSKER

\title{
WILL LUTHER'S EXCOMMUNICATION BE LIFTED IN 2021? A PLEA OF THE ALTENBERG ECUMENICAL ROUND TABLE*
}

\begin{abstract}
A bstract. The Altenberg Ecumenical Round Table appeals in a declaration or appeal to Pope Francis asking him to lift the ban on Martin Luther and his followers, while appealing to the Lutheran World Federation to remove from the confessions the passages calling the Pope Antichrist. I describe the release of the Altenberg Appeal and the publication of the book on the subject, including its background and the first reactions to both. Finally, I explain my own position here.
\end{abstract}

Keywords: Altenberg Appeal; Ecumenism; Luther; Excommunication; Joint Declaration; Confessio Augustana.

\section{INTRODUCTION}

In this article, I want to draw your attention to the plea of the Altenberg Ecumenical Round Table (AERT) for the withdrawal of the excommunication of Martin Luther and his followers by Pope Francis. The AERT puts the question on the ecumenical agenda. It has already been raised earlier several times, unofficially and officially. ${ }^{1}$ One of the obstacles seems to be canon law. Here I can see a parallel with the Jewish discussions in the Netherlands concerning the excommunication of Baruch de Spinoza in Amsterdam in

Rev. Dr. MARGRIET GOSKER, Doctor of Ecumenical Theology; a member of the Faith and Order Section of the Council of Churches in the Netherlands; e-mail: dr.m.gosker.venlo@hetnet.nl.

* I thank Rev. Harvey Richardson, a Methodist minister in Britain, for correcting my English.

${ }^{1}$ Cf. the Worms Memorandum (1971). Archbishop Wim Eijk incited the anger of prominent Dutch Protestants (2014), saying that the council of Trent is still fully valid - "Protestanten boos op kardinaal Eijk vanwege "vervloeking'," Trouw, January 7, 2014; "Rehabilitiert der Papst Martin Luther?", see https://www.landeskirche-hannovers.de/evlka-de/presse-und-medien/nachrichten/2008/ 03/07-8014 (all websites accessed in March, 2021). 
1656, also not lifted for reasons of canon law. ${ }^{2}$ On the other hand, Pope John Paul II did express his gratitude for the moral integrity of Johannes Hus (1990), a kind of rehabilitation, but without an orderly basis. Also Galileo Galilei was rehabilitated (1992) by him, but also without a clear grounding in canon law.

Protestants in turn should be aware of their own verbal abuses, anchored in some of their own confessions. ${ }^{3}$ In those stormy Reformation times, Martin Luther and John Calvin both sharply criticized the papacy. ${ }^{4}$ John Calvin repeatedly calls the pope the Antichrist. ${ }^{5}$ Therefore, it is necessary for these Protestant accusations of the 16 th century also to be taken back. ${ }^{6}$ I am glad to present here the content of the Altenberg Declaration on Reconciliation, or

${ }^{2}$ In Amsterdam (December, 2015), there was a plea for lifting the excommunication by Nathan Lopez Cardozo, https://niw.nl/in-godsnaam-vernietig-de-ban-op-spinoza-555. Pinchas Toledano, Chief Rabbi of the Portuguese-Israelite Congregation (Amsterdam) concluded that withdrawal is impossible due to reasons of church law (הלכה); see Reformatorisch Dagblad, December 7, 2015. I thank Reinier Gosker for his information; see https://www.rd.nl/artikel/642266-banvloek-overspinoza-niet-opgeheven.

${ }^{3}$ Hans-Georg Link, "Vom 'Antichrist' zum 'Bruder' in Christus. Zur Aufarbeitung des reformatorischen Antichrist-Verdikts gegen das Papsttum," in In alle Ewigkeit verdammt? Der Konflikt zwischen Luther und Papst nach 500 Jahren, Eine Stellungnahme des Altenberger Ökumenischen Gesprächskreises, ed. Hans-Georg Link and Josef Wohlmut (Göttingen: Vandenhoeck \& Ruprecht; Ostfildern: Grünewald, 2020).The pope as Antichrist occurs in Lutheran and non-Lutheran Confessions. The preface of the Dordtse Leerregels states that the church was delivered by God's mighty hand from the tyranny of the Roman Antichrist and from the terrible idolatry of the papacy (https://www.gkv.nl/downloads/5952/Dordtse_Leerregels.pdf). Since 1957, this preface has no longer been mentioned in the official text of this confession in the Protestant Church in the Netherlands. In other Reformed wings it is still there. I discovered, that in the same way the prophet Mohammed has been suppressed in a new edition of Dante's Divina Comedia, see https://www.standaard.be/cnt/ dmf20210322_98057472. The Westminster Confession states: "There is no other head of the Church but the Lord Jesus Christ. Nor can the Pope of Rome, in any sense, be head thereof: but is that Antichrist, that man of sin, and son of perdition" (xxv, 6). In 2018 the General Assembly of the Presbyterian Church of Aotearoa (New Zealand) made the following decision in relation to the Westminster Confession: "Those statements in the Westminster Confession of Faith which assert that all monastic vows are 'superstitious and sinful snares', that the pope is antichrist, that Protestants may never marry Catholics, and that the Catholic mass is 'abominably injurious' should be understood as reflecting the very sharp divisions, antagonisms, and dangers of the Reformation era and its aftermath, and should not be interpreted as applicable in today's context." The text is available at https://www.presbyterian.org.nz/about-us/statements-of-faith/westminster-confession-1646.

${ }^{4}$ Calvin said that the pope's tyranny was harsh and cruel, seeJohannes Calvijn, Het gepredikte woord, vol. 3, Preken van Johannes Calvijn vertaald door J. Douma en W.H. v.d. Vegt, part 5, Preken over de kerk (Franeker: Wever, 1978), 30.

${ }^{5}$ Johannes Calvijn, Institutie of onderwijzing in den christelijken godsdienst, uit het Latijn vertaald door A. Sizoo, part 3, book 4, chapter 7, §25 and chapter 9, §4 (Delft: Meinema, s.d., [1931]), 157, 184.

${ }^{6}$ Calvin distinguishes between cutting off and anathema (or curse), because the latter is without the hope of forgiveness and surrenders to eternal destruction (Calvijn, Institutie, 266). 
better the Altenberg Appeal, ${ }^{7}$ and the book In alle Ewigkeit verdammt?, published by the AERT in $2020 .^{8}$ Then I will present and evaluate some responses on it.

\section{THE VIEW OF MGR. RADANO}

In 2005, I asked Mgr. John Radano, ${ }^{9}$ who was at the time the Secretary of the Pontifical Council for Promoting Christian Unity (PCPCU), if, in his view, it was possible after five hundred years for the Vatican to lift the ban on Luther. I had the opportunity to meet Mgr. Radano in Utrecht, where he was the first Roman Catholic consultant during a gathering of the 14th Assembly of the Reformed Ecumenical Council (REC), now absorbed in the new World Communion of Reformed Churches (WCRC). ${ }^{10}$ His answer was friendly and clear. "Martin Luther died, and so it is impossible to lift his excommunication." I protested, saying that it would be rehabilitation not only for the deceased Luther, but also for his followers - especially for those who are still alive. Therefore, assuming this answer from Mgr. Radano is correct, nothing can be done, unless there are precedents. ${ }^{11}$ An optimistic way to solve the ecumenical problem would be to change Roman Catholic canon law, but I cannot foresee that happening.

${ }^{7}$ https://www.altenberger-gespraeche.de/altenberg-declaration-reconciliation-after-500-years. I prefer the term "appeal", because I think that is what it really is.

${ }^{8}$ Hans-Georg Link and Josef Wohlmuth, eds., In alle Ewigkeit verdammt? Zum Konflikt zwischen Luther und Papst nach 500 Jahren. Eine Stellungnahme des Altenberger Ökumenischen Gesprächskreises (Göttingen: Vandenhoeck \& Ruprecht; Ostfildern: Grünewald, 2020); see footnote 4.

${ }^{9}$ John A. Radano, Lutheran and Catholic Reconciliation on Justification: A Chronology of the Holy See's Contributions, 1961-1999, to a New Relationship between Lutherans and to Steps Leading to the Declaration on the Doctrine of Justification (Grand Rapids, MN: William B. Eerdmans, 2009).

${ }^{10}$ The Reformed Ecumenical Council (REC) and the World Alliance of Reformed Churches (WARC) united into the World Communion of Reformed Churches (WCRC) in Grand Rapids in the year 2010. On the history of REC see Margriet Gosker, ed., A Man for All Seasons. Essays in Recognition of Work of Richard van Houten for the Reformed Ecumenical Council 1987-2010 (Grand Rapids, MN: Reformed Ecumenical Council, 2010). The WCRC is comprised of 100 million Christians in Congregational, Presbyterian, Reformed, United, Uniting and Waldensian churches and working with its 233 member churches, is active in supporting theology, justice, church unity and mission in over 105 countries; in support of this see http://wcrc.ch/about-us.

${ }^{11}$ Karim Schelkens wrote me (March 15, 2021) that Radano's argument seems rather weak and was used during a period of great influence of Cardinal Ratzinger, who was reluctant to change things or step forward. Radano probably anticipated the expected answer of the Congregation for the Doctrine of the Faith. The reconciliation of 1054 could be argued against Radano as a precedent indeed. This event was not expected at the time and considered totally impossible. 
It is interesting, that at this same REC Assembly a question was put on the agenda, about whether or not the Reformed family could withdraw a sentence from the Heidelberg Catechism, which says that the Mass is a damned idolatry ("ein vermaledeyte abgötterey"). ${ }^{12}$ I remember a remark of Mgr. Radano: "In those times we did not really communicate, because we did not meet each other. We just wrote down our statements and judgements. This is not a way leading to balanced texts. But in our time the dialogue is open."13

The REC Council was open to the idea of withdrawal; however, they acknowledged how highly problematic it is to make changes to a historical text. What happened in history cannot be changed, and we should learn to solve our problems in other ways. There was a suggestion to add a footnote to the original text. Nevertheless, in the present edition of the confessions of the Protestant Church in the Netherlands, nothing has been changed. The sentence that the Mass is a "vervloekte afgoderij" is still there, without a footnote. ${ }^{14}$

\section{WHERE ARE WE NOW?}

Sometimes it crosses my mind that a new Reformation might start again in Germany. I see all kinds of initiatives for church renewal emerging in our neighbouring country, such as the "Gemeinsam am Tisch des Herrn" project, ${ }^{15}$ the ongoing process of "Der Synodale Weg," the idea of both Protestant and Roman Catholic Christians under one $\operatorname{roof}^{17}$ and the movement Maria 2.0. ${ }^{18}$

\footnotetext{
${ }^{12}$ Ernst Friedrich Karl Müller, ed., Die Bekenntnisschriften der reformierten Kirche. In authentischen Texten mit geschichtlicher Einleitung und Register, Theologische Studien - Texte 5.2 [Nachdruck der Ausgabe Leipzig, 1903] (Waltrop: Spenner, 1999), 704.

13 "Gereformeerden zien mis niet langer als afgoderij," Trouw, July 21, 2005, https://www.trouw.nl/ nieuws/gereformeerden-zien-mis-niet-langer-als-146-afgoderij-146 b92182fa.

${ }^{14}$ The Heidelberg Catechism (1563) is mainly the work of Zacharias Ursinus. It was Caspar Olevianus, who was responsible for the addition of the Lord's Day Question and Answer 80: a strong rejection of the Mass, which appeared only in the last edition under the influence of Theodorus Beza. Cf. Wim Moehn, "Mis als 'vervloekte afgoderij' verraadt de context van Trente," Protestants Nederland 85, no. 3 (2021): 66; Klaas Zwanepol, Belijdenisgeschriften voor de Protestantse Kerk in Nederland (Zoetermeer: Boekencentrum, 2004), 73, 91.

${ }^{15}$ Volker Leppin and Dorothea Sattler, eds., "Gemeinsam am Tisch des Herrn" - Ein Votum des Ökumenischen Arbeitskreises evangelischer und katholischer Theologen (Freiburg im Breisgau: Herder; Göttingen: Vandenhoeck \& Ruprecht, 2020).

16 "Bisschop Bätzing: 'Synodale Weg' vervolgen in dialoog met Rome," Katholiek Nieuws, January 5, 2021, https://www.kn.nl/duitsland/bisschop-batzing-synodale-weg-vervolgen-in-dialoogmet-rome.

${ }^{17}$ The Evangelical Lutheran Bishop Ralf Meister believes that parishes of different confessions "under one roof" are possible in the future, he said in an interview with the Evangelical Press Service.
} 
The AERT initiative shows great ecumenical commitment, and a desire to clean up things. Now is the time - after a long journey - to put our earlier conflicts behind us. In the years after the Second Vatican Council, the Ecumenical Movement is strong. Many theologians of different traditions made their contributions to the goal of "visible unity", trying to overcome the difficulties of the past by praying, studying, and especially listening to each other. There were influential ecumenical dialogues such as (concisely) the project on Baptism, Eucharist and Ministry (BEM), leading to the famous Lima-Document (1982). ${ }^{19}$ Martin Luther, once accused of heresy, could now be seen as a "witness to Jesus Christ" (1983). ${ }^{20}$ The project "Doctrinal Condemnations - Church Dividing?" (1986) ${ }^{21}$ was a big step forward. The process leading to the Joint Declaration on the Doctrine of Justification (JDDJ) was a historic agreement, signed in Augsburg (1999). ${ }^{22}$ The document From Conflict to Communion ${ }^{23}$ (2013) was a preparation for the upcoming Reformation Commemoration Year 2017. In 2015, at the start of my leadership for

The Hildesheim bishop Heiner Wilmer welcomed the reflections of his Protestant colleague; see "Bischof Wilmer begrüßt Vorschlag zu 'ökumenischen Gemeinden',' Katholisch, January 3, 2020, https:// www.katholisch.de/artikel/24094-bischof-wilmer-begruesst-vorschlag-zu-oekumenischen-gemeinden.

${ }^{18}$ Margriet Gosker, "Maria 2.0,” Mariënburg Magazine 37 (2020): 5, 14-16. In Passau (2002) seven Roman Catholic women were ordained as priests by Bishop Rómulo Braschi contra legem on a boat on the Danube River between Germany and Austria. Margriet Gosker, "Gods 'ja' en het 'nee' van de kerk. Ambtstheologische notities bij de vrouw in het ambt," in Honderd jaar vrouwen op de kansel, 1911-2011, ed. Mirjam de Baar et al. (Hilversum: Verloren, 2011), 53-65. Braschi was excommunicated on August 5, 2002.

${ }^{19}$ Protestants reflected on the episcopal office as the focus of unity, see Margriet Gosker, Het kerkelijk ambt in het Limadocument. Een hermeneutische doorlichting en een kritische evaluatie van de Lima-Ambtstekst (Utrecht: IIMO Research Publication, 1990). Unfortunately, the document has now been forgotten and is landed in the refrigerator, waiting for a new life. Margriet Gosker, "Wer dafür eine Nase hat... Das Lima-Dokument 30 Jahre später - Fokus: Die Niederlande," Una Sancta 67, no. 3 (2012): 220. Heidi Zitting, The Episcopal Office in transition. Finnish Lutheranism and the Lutheran World Federation Discussions on Episkope 1945-2015 (Helsinki: Faculty of Theology, 2020).

${ }^{20}$ Lutheran-Roman Catholic Commission on Unity, "Martin Luther - Witness to Jesus Christ," christianunity, http://www.christianunity.va/content/unitacristiani/en/dialoghi/sezione-occidentale/ luterani/dialogo/documenti-di-dialogo/en13.html.

${ }^{21}$ Karl Lehmann and Wolfhart Pannenberg, Lehrverurteilungen-kirchentrennend?, vol. 1, Rechtfertigung, Sakramente und Amt im Zeitalter der Reformation und heute (Freiburg im Breisgau: Herder, Vandenhoeck \& Ruprecht, $\left.1986^{3}\right)$.

${ }^{22}$ Available at http://www.christianunity.va/content/unitacristiani/en/dialoghi/sezione-occidentale/ luterani/dialogo/documenti-di-dialogo/1999-dichiarazione-congiunta-sulla-dottrina-della-giustificazion/ en.html.

${ }^{23}$ From Conflict to Communion: Lutheran-Catholic Common Commemoration of the Reformation in 2017 (Leipzig: Evangelische Verlagsanstalt-Bonifatius, 2013), available at https://www.lutheran world.org/sites/default/files/From\%20Conflict\%20to\%20Communion.pdf. 
this Jubilee in the Netherlands, I was convinced that we were obliged to pay special attention to the ecumenical perspectives, and so we did. ${ }^{24}$ At the opening event (Amsterdam, October 31, 2016), emphasis was placed on the fact that for the first time in history, Roman Catholics were officially taking part in the Commemoration of the Reformation. ${ }^{25}$ On the same day, Pope Francis was present at the official opening of the Reformation Year in Lund in Sweden. Modern technology made it possible for us to follow this event "live on screen" in Amsterdam. ${ }^{26}$ Pope Francis also said (January 19, 2017) that Luther's intention was "to renew the Church, not divide her." 27

"Restoration of unity is today's Reformation" 28 - these words come from a joint declaration of the Rome-Reformation Dialogue Group in our country (published March 8, 2017). ${ }^{29}$

\section{UP TO 2030?}

The AERT is hoping for official church fellowship in 2030, but therefore it is imperative to remove the obstacles still standing in the way. In 2017 in Wittenberg, the German bishop Heinrich Bedford-Strohm, president of the Evangelical Church of Germany (EKD), expressed his hope that unity (in reconciled diversity) could be realised in the year $2030 .{ }^{30}$ In that year it will be 500 years since the Confessio Augustana, the most important Lutheran confession, flowed from the pen of Philippus Melanchthon.

\footnotetext{
${ }^{24}$ Margriet Gosker, "500 Jahre Protestantismus in den Niederlanden," in Zeit der Versöhnung, Wege in die Zukunft der Ökumene, ed. Hans-Georg Link and Dorothea Sattler (Göttingen: Vandenhoek \& Ruprecht, 2017), 90.

${ }^{25}$ Margriet Gosker, “Eros vár a mi istenünk,” Sárospataki Füzetek 21 (2017): 2, 42.

${ }^{26}$ Margriet Gosker, "Luther's Legacy after 500 years,” Studia Podlaskie 25 (2017): 8-31.

${ }^{27} \mathrm{He}$ spoke to members of an ecumenical delegation from Finland on the occasion of the feast of St. Henrik. The address is available at http://www.vatican.va/content/francesco/en/speeches/2017/ january/documents/papa-francesco_20170119_delegazione-finlandia.html.

${ }^{28}$ Margriet Gosker, "Samen op weg-Gaandeweg één. 500 jaar Reformatie en Oecumene," Perspectief, Internettijdschrift van de Katholieke Vereniging voor Oecumene, April 3, 2017, https://www.oecumene.nl/documentatie/500-jaar-reformatie/1337-samen-op-weg-gaandeweg-een-500jaar-reformatie-en-oecumene.

${ }^{29}$ See the address of the Rome-Reformatieberaad titled "Herstel van eenheid is de Reformatie van vandaag. Uitnodiging aan alle christenen in Nederland bij de herdenking van 500 jaar Reformatie," given on March 18, 2017. The text is available at https://www.oecumene.nl/romereformatieberaad/1331-herstel-van-eenheid-is-reformatie-van-vandaag.

${ }^{30} \mathrm{He}$ said it in his sermon at the celebration of the Lima Liturgy during the Reformation Year in the Wittenberg Stadtkirche (August 27, 2017). Hans-Georg Link, Inge Keidel and Rudolf Weth, eds., Dokumentation der Wittenberger Ökumenischen Versammlung (Köln: privately printed, 2018).
} 
The Augsburg Confession of 1530 was the last major attempt within the Reformation to save the unity of the Church. In this respect, its 500th anniversary in 2030 is - according to Christian Schad - worthwhile as a target date for an ecumenical breakthrough. ${ }^{31}$ The idea is sustained by Father Augustinus Sander, who sees the challenge of whether or not we can profess our faith in a larger community in $2030 .^{32}$

\section{THE ALTENBERG APPEAL, ITS MEANING AND CONTENT}

From the very beginning (1999), I have been a member of the Altenberg Ecumenical Round Table, ${ }^{33}$ an ecumenical German-speaking group founded in Cologne. ${ }^{34}$ In 2018 we gathered in Münster. When the idea was launched that we should focus on the year 2021 - five hundred years after Luther's excommunication - I said, "If we ever want to stimulate Rome to lift the excommunication of Martin Luther, this is exactly the right time to do so." 35 Nevertheless, the response from Mgr. Radano still crossed my mind.

The AERT refers to the fact that Martin Luther, in his Schmalkald Articles of 1537, restated his accusation (already raised in 1520) that the Antichrist was seated on the papal chair, that the pope raised himself above

${ }^{31}$ Christian Schad was in 2017 president of the Evangelical Church of the Palatinate. Schad has chaired the Ecumenical Working Group of Protestant and Catholic Theologians (ÖAK) since 2020; see "Protestanten nennen 2030 als Zielmarke für ökumenischen Durchbruch," EKD, November 11, 2017, https://www.ekd.de/protestanten-nennen-2030-als-zielmarke-fuer-oekumene-30500.htm.

${ }^{32}$ Augustinus Sander is a Benedictine Father of Maria Laach Abbey in Germany, and in PCPCU he is responsible for the dialogue with the Lutheran churches and the Old Catholic churches of the Union of Utrecht; see his "Pater Sander: 'Wir müssen über den eigenen Kirchturm hinausschauen'," Vatican News, January 5, 2021, https:/www.vaticannews.va/de/vatikan/news/2021-01/vatikanoekumene-pater-sander-itv-geleitwort-rechtfertigung-text.html.

${ }^{33}$ Altenberger Ökumenischer Gesprächskreis, https://www.altenberger-gespraeche.de.

${ }^{34}$ The Altenberg Ecumenical Round Table provided several books with ecumenical themes: HansGeorg Link, ed., Unsere ökumenische Zukunft. Altenberger Symposion, 27. bis 29. August 1999, Kölner Ökumenische Beiträge 41 (Köln, 2000); Johannes Brosseder and Hans-Georg Link, eds., Eucharistische Gastfreundschaft. Ein Plädoyer evangelischer und katholischer Theologen (Neukirchen: Neukirchener Verlagshaus, 2003); Johannes Brosseder and Joachim Track, eds., Kirchengemeinschaft jetzt! Die Kirche Jesu Christi, die Kirchen und ihre Gemeinschaft (Neukirchen: Neukirchener Verlagsgesellschaft, 2010); Hans-Georg Link and Dorothea Sattler, eds., Zeit der Versöhnung. Wege in die Zukunft der Ökumene (Göttingen: Vandenhoeck \& Ruprecht, 2017).

${ }^{35}$ Maarten Stolk and Klaas van der Zwaag, "Banvloek Luther opnieuw ter discussie," Reformatorisch Dagblad, January 9, 2021, p. 10-11. 
Christ, and that the Church had fallen into idolatry. ${ }^{36}$ As a reformed pastor I am well aware that the Heidelberg Catechism, first published in $1563,{ }^{37}$ states that the Mass is a damned superstition. ${ }^{38}$ It is obvious, that love cannot come from only one side. Therefore, if Pope Francis would be willing to withdraw Luther's excommunication, the Protestants, in their turn, should affirm their withdrawal of the things they said about the pope as the "Antichrist", etc. The AERT decided to take the lead by studying various aspects of the topic, making a written statement and publishing a book to draw public attention to this important issue.

The text of the Altenberg Appeal was established at Pentecost, May 31, 2020, signed by Hans-Georg Link and Josef Wohlmuth. It was published (November 25, 2020) as a plea for the withdrawal of the Excommunication Bull by Pope Leo X delivered against Martin Luther and all his followers. It also calls for a reversal of the Reformers' condemnations of the Pope as "Antichrist." The appeal mentions the tragic events of the years 1520-1521 that made Martin Luther and Pope Leo X irreconcilable adversaries.

The papal bull Exsurge Domine ${ }^{39}$ of June 15, 1520 condemned Martin Luther's errors, which threatened Luther and all his followers. ${ }^{40}$ Four years

36 "Haec doctrina praeclare ostendit papam esse ipsum verum Antichristum, qui supra Christum sese extulit..."; see Die Bekenntnisschriften der evangelisch-lutherischen Kirche, herausgegeben im Gedenkjahr der Augsburger Konfession 1930 (Göttingen: Vandenhoeck \& Ruprecht,1998), 430 (hereafter BSLK).

${ }^{37}$ Available at http://www.heidelberg-catechism.com/pdf/lords-days/Heidelberg-Catechism.pdf.

${ }^{38}$ Question 80: What difference is there between the Lord's supper and the papal mass? Answer: The Lord's supper testifies to us, first, that we have complete forgiveness of all our sins through the one sacrifice of Jesus Christ, which he himself accomplished on the cross once for all; and, second, that through the Holy Spirit we are grafted into Christ, who with his true body is now in heaven at the right hand of the Father and this is where he wants to be worshipped. But the mass teaches, first, that the living and the dead do not have forgiveness of sins through the suffering of Christ unless he is still offered for them daily by the priests; and, second, that Christ is bodily present in the form of bread and wine, and there is to be worshipped. Therefore the mass is basically nothing but a denial of the one sacrifice and suffering of Jesus Christ, and an accursed idolatry.

${ }^{39}$ Exsurge Domine (Arise, O Lord): "If, however, this Martin, his supporters, adherents and accomplices, much to our regret, should stubbornly not comply with the mentioned stipulations within the mentioned period, we shall, following the teaching of the holy Apostle Paul, who teaches us to avoid a heretic after having admonished him for a first and a second time, condemn this Martin, his supporters, adherents and accomplices as barren vines which are not in Christ." Available at https://www.papalencyclicals.net/leo10/110exdom.htm.

${ }^{40}$ Leo X issued a bull "condemning, reprobating and rejecting completely" forty-one of Luther's theses. He called them "errors ... either heretical, scandalous, false, offensive to pious ears or seductive of simple minds, and against Catholic truth." Luther was given 60 days to recant or be expelled. Luther did not step aside, but reaffirmed his position and added: "Whoever wrote that Bull, he is Antichrist." On the day of the deadline, Luther and his fellow-reformer Philippus Melanchthon burned a copy of the bull and some other papal documents. 
earlier, in 1517, the German monk would have nailed his Ninety-Five Theses to the Wittenberg's church door, as the famous story tells us. Is it a legend or is it an accurate account $?^{41}$ Nevertheless, his 95 theses were published, and thanks to the newly invented printing press, they were spread across Europe in a very short time. After half a year Exsurge Domine was followed by Decet Romanum Pontificem, ${ }^{42}$ the official Papal Bull of Excommunication of Martin Luther and his followers (January 3, 1521). The Diet of Worms received this Bull on February 13, from the papal legate, Hieronymus Alexander. Martin Luther was summoned to the Diet and there he stood on April 18, 1521, in front of all these powerful men, including Emperor Charles V. All of this led to the Edict of Worms, ${ }^{43}$ depriving Martin Luther and all his followers of all their rights. Nevertheless, Luther refused to obey, and the schism quickly spread across Christian Europe. Terrible wars and persecutions ensued, as monarchs and nobles took sides.

The Altenberg Appeal points out that the ecumenical dialogues following the second Vatican Council show how new views have emerged on both sides. One of the most fundamental theological conflicts was resolved by the Joint Declaration on the Doctrine of Justification. Initially it was just a CatholicLutheran agreement, but three other Christian World Communions have also affirmed it. The World Methodist Council endorsed the JDDJ in 2006, ${ }^{44}$ the

${ }^{41}$ According to Richard Rex et al. it is a legend that Martin Luther nailed the Ninety-Five Theses to the doors of the Castle Church in Wittenberg on October 31, 1517; see Richard Rex, The making of Martin Luther (Princeton: Princeton University Press, 2017), 9; see online Michael Driscoll's review of Rex's book, available at https://www.euppublishing.com/doi/full/10.3366/ more.2019.0064.

42 Decet Romanum Pontificem, §5: "We would make known to all the small store that Martin, his followers and the other rebels have set on God and his Church by their obstinate and shameless temerity. We would protect the herd from one infectious animal, lest its infection spread to the healthy ones. Hence we lay the following injunction on each and every patriarch, archbishop, bishop, on the prelates of patriarchal, metropolitan, cathedral and collegiate churches, and on the religious of every Order - even the mendicants - privileged or unprivileged, wherever they may be stationed: that in the strength of their vow of obedience and on pain of the sentence of excommunication, they shall, if so required in the execution of these presents, publicly announce and cause to be announced by others in their churches, that this same Martin and the rest are excommunicated, accursed, condemned, heretics, hardened, interdicted, deprived of possessions and incapable of owning them."

${ }^{43}$ Emperor Charles V passed the Edict of Worms. Luther's writings were banned and Luther was declared a heretic and also an enemy of the State. Although the Edict claimed that Luther should be captured and turned over to the emperor, it never happened.

44 "We, the Churches joined together in the World Methodist Council, welcome this agreement with great joy. We declare that the common understanding of justification as it is outlined in the 
World Communion of Reformed Churches and the Anglican Communion followed suit in 2016. ${ }^{45}$ The Declaration focused on the message of the redemption by Christ as the basis of faith: "Together we confess: By grace alone, in faith in Christ's saving work and not because of any merit on our part, we are accepted by God and receive the Holy Spirit, who renews our hearts while equipping and calling us to good works ( 15$). "{ }^{46}$ Comment on the doctrinal condemnations of the 16th century was stated in $\S 41$ : "Thus the doctrinal condemnations of the 16th century, in so far as they relate to the doctrine of justification, appear in a new light: the teaching of the Lutheran Churches presented in this declaration does not fall under the condemnations from the Council of Trent. The condemnations in the Lutheran Confessions do not apply to the teaching of the Roman Catholic Church presented in this declaration." Therefore, the AERT is convinced that the time is ripe - in this year (2021) of the "anniversary" of Decet Romanum Pontificem - for Martin Luther and all of his followers to receive a new judgement. This should include Martin Luther's condemnation by Pope Leo X, as well as Luther's condemnation of the pope as "Antichrist".

Furthermore, the Altenberg Appeal shows it has been inspired by an earlier important event. On December 7, 1965, on the last day before the closing of

Joint Declaration on the Doctrine of Justification (JDDJ 15-17) corresponds to Methodist doctrine. We are especially grateful for the trinitarian approach by which God's work in salvation is explained" - available at https://worldmethodistcouncil.org/wmcs-statement-of-assocation-with-thejoint-declaration-of-the-doctrine-of-justification.

${ }^{45}$ In March 2019 the leaders of the five World Communions came together at Notre Dame University in the United States to celebrate the 20th Anniversary of the JDDJ and they issued a statement (The Notre Dame Consultation Statement): "Our churches face similar challenges in communicating the meaning of justification to today's society in ways in which meet the experiences and needs of the world. We are gripped with the imperative of proclaiming the good news of salvation, through compassion and working for justice" (https://news.nd.edu/assets/315013/ jddj_nd_final_statement.pdf).

${ }^{46}$ We must realise that the reception of JDDJ was not only positive. Many theologians of both sides were critical, stating that the real differences are still not solved. Leonardo De Chirico puts the question if the Roman Catholic Church now is really committed to "Grace Alone"; see https:// vaticanfiles.org/en/2017/08/140-is-the-roman-catholic-church-now-committed-to-grace-alone. The critical "Is the Reformation Over?" statement (signed by 200 pastors and theologians) summarizes: "On the doctrine of salvation, many are under the impression that there is a growing convergence regarding justification by faith and that tensions between Catholics and Evangelicals have eased considerably since the sixteenth century. At the Council of Trent (1545-1563), the Roman Catholic Church reacted strongly against the Protestant Reformation by declaring "anathema" (cursed) those who upheld justification by faith alone, as well as affirmed the teaching that salvation is a process of cooperating with infused grace rather than an act grounded in grace alone by faith alone.... Roman Catholic theology may use the same language as Evangelical theology, yet mean very different things." 
the Second Vatican Council, a joint Declaration of Reconciliation between Rome and Byzantium was proclaimed in the presence of Pope Paul VI. The Dutch Bishop Johannes Willebrands, with Metropolitan Melton on his side in Rome, presented this declaration, overcoming the 1054 anathemas. ${ }^{47} \mathrm{Sim}-$ ultaneously, the same text was presented by the Metropolitan Chrysostom of Myra in St. Gregory's Cathedral in the Fanar region of Constantinople in the presence of Athenagoras I, the Ecumenical Patriarch of Constantinople. ${ }^{48}$ It is impossible to pretend that these Anathemas were not what they were during this troubled period of history. However, in the 20th century, they should be judged differently. The Pope and the Patriarch jointly declared ${ }^{49}$ that they regretted the mutual excommunications in the year 1054 and would like to "remove them from memory and from the midst of the Church." 50 They had to be forgotten. ${ }^{51}$ We can ask whether it was - according to ecclesiastical law - a true withdrawal of the old anathemas. It was certainly an important gesture of reconciliation, and an attempt to erase the old schism from memory. But is it still necessary for further steps to follow?

\section{WHAT DID THE ALTENBERG ECUMENICAL ROUND TABLE DO?}

The AERT wrote letters to Pope Francis, to Archbishop Musa Panti Filibus of the Lutheran World Federation (LWF), to the German Bishops Conference, and to the Evangelical Church in Germany (EKD), but consciously

\footnotetext{
${ }^{47}$ It was his finest hour, says Karim Schelkens in Johannes Willebrands. Een leven in gesprek (Amsterdam: Boom Uitgevers, 2020), 287; Schelkens, "Re-Interpreting Historical Dividedness. The Hierarchy of Councils as a Means for Christian Unity," in The Normativity of History: Theological Truth and Tradition in the Tension between Church History and Systematic Theology, ed. Lieven Boeve, Mathijs Lamberigts, and Terrence Merrigan (Leuven: Peeters Publishers, 2016), 67-99.

${ }^{48}$ Athenagoras's meeting with Pope Paul VI in 1964 in Jerusalem led to the rescinding of the excommunications of 1054 (the Great Schisma) which mark the schism between the Churches of the East and West. This was a significant step towards restoring communion between Rome and Constantinople and the other patriarchates of Orthodoxy. It produced the Catholic-Orthodox Joint Declaration of his Holiness Pope Paul VI and the Ecumenical Patriarch Athenagoras I (December 7, 1965).

49 "Regretter également et enlever de la mémoire et du milieu de l’Église les sentences d'excommunication, qui les ont suivis, et dont le souvenir opera jusqu'à nos jours comme un obstacle au rapprochement dans la charité, et les vouer à l'oubli” (Schelkens, "Re-interpreting," 87).

${ }^{50}$ Available at http://www.vatican.va/content/paul-vi/en/speeches/1965/documents/hf_p-vi_spe_ 19651207_common-declaration.html.

${ }^{51}$ Anton Houtepen, Anatomie van het anathema. Over uitsluiting en verzoening, verdeeldheid en hereniging in het oecumenisch proces, Utrechtse theologische reeks 48 (Utrecht: Universiteit Utrecht, 2004), 32.
} 
chose to approach the ordinary German parishioners and congregation members as well, by means of an open letter. Until now, there was no contact with the World Communion of Reformed Churches (WARC).

1. The AERT requested (November 13, 2020) the current Bishop of Rome (in consultation with PCPCU), to declare that the condemnations of the Bull of Excommunication of 1521 "do not apply to today's members of Evangelical Lutheran Churches." 52 The AERT refers to the Worms Memorandum of March 6, 1971, the "anniversary' of Luther's excommunication after 450 years. Roman Catholics from Worms wrote this memorandum, asking Pope Paul VI to announce a word of clarification concerning the person and teaching of Martin Luther from today's Roman Catholic point of view, and to take further ecumenical steps. ${ }^{53}$ The AERT expresses the hope that what was not possible around fifty years ago could be achieved in 2021. The letter was answered by the Vatican (December 21,2020$),{ }^{54}$ promising that a common word of the Vatican and the LWF on the excommunication of Luther, and all his followers, will follow soon.

I have three comments. My first is that not all followers of Martin Luther belong to these Lutheran denominations. Other Protestants and certainly the Reformed wing of the Reformation should be included here. ${ }^{55}$ Secondly, I point out that a negative response on the Worms Memorandum came from the Vatican in a letter of July 14, 1971, written by Cardinal Johannes Willebrands. He was PCPCU's secretary at that time and a leading force in ecumenical affairs. The abolition of Luther's excommunication, however, was not his first priority, probably for reasons of church politics. ${ }^{56}$ My third

\footnotetext{
52 In aller Ewigkeit verdammt? 32.

53 Rudolf Knecht, Paul Sürder, and Leonhard Veith, Aus gegebenem Anlass erbitten Wormser Katholiken von Papst Paul VI. ein klärendes Wort zur Person und Lehre Martin Luthers aus heutiger katholischer Sicht im Interesse der Vertiefung ökumenischer Arbeit (Worms, 1971). Reprint, Fritz Reuter, ed., 1521 - Luther in Worms - 1971. Ansprachen, Vorträge, Predigten und Berichte zum 450-Jahrgedenken (Worms, 1973), 175-89.

54 This answer of Archbishop Edgar Peña Parra has been included in the second edition of In aller Ewigkeit verdammt?, which appeared after this article was finished (pp. 208-9).

55 The Reformed are scarcely included, for example, in In alle Ewigkeit verdammt? 147.

56 "La levée de l'excommunication portée contre Luther ne semble ni possible sur le plan objectif, ni appropriée" - quotation from Marc Lienhard, Martin Luther, un temps, une vie, un message (Paris: Le Centurion, 1983), 411-12. I thank Karim Schelkens for his help. He told me in his e-mail of March 15,2021 , that Willebrands could certainly speak in a positive way, saying that Luther was a Doctor Communis (a common teacher of the Church), a title mostly given to Thomas Aquinas. Find the whole Text of Cardinal Willebrands in Herder-Korrespondenz 24 (1970): 427-31. Cf. Brosseder, "Luther im Urteil der gegenwärtigen katholischen Theologie,“ in Link and Wohlmuth, In alle Ewigkeit verdammt? 113.
} 
remark is that the request to Pope Francis to declare that Luther's excommunication does not apply to present-day Lutherans is already implicitly stated in Unitatis Redintegratio, $\S 3$ and in the JDDJ, $\S 41$.

2. The AERT requested Archbishop Musa Panti Filibus (from Nigeria), today's president of the LWF, to declare (in consultation with the Executive Committee of the LWF) that the condemnation of the Pope as "Antichrist" by Martin Luther and Lutheran confessional writings ${ }^{57}$ do not apply to the present papacy and its ministers. ${ }^{58}$ The AERT urges LWF to revoke Luther's condemnation of the pope as "Antichrist." It would be a strong ecumenical sign, if - in a common act, perhaps taking place at the same time in different locations - both sides could extinguish the words and deeds which led both to the excommunication of Luther and to the "Antichrist" condemnations. The LWF responded (January 25, 2021), expressing sympathy for all the work done to overcome the distance of centuries, referring to JDDJ and to $\S 16$ of the document From Conflict to Communion. ${ }^{59}$ The letter also referred to the message in the Cathedral of Lund (2016), where both sides regretted the divisions of the past and promised to approach one another from a perspective of unity. The LWF and PCPCU have recently updated all translations and accompanying documents of the JDDJ, saying: "Noteworthy, this year was the addition of an updated Italian translation of JDDJ and first-time translations of all the accompanying documents. These were rendered public

57 "Thus the Papacy also will be a part of the kingdom of Antichrist if it thus defends human services as justifying" ("Ita et papatus erit pars regni antichristi, si sic defendit humanos cultus quod iustificent") - Apology of the Augsburg Confession, Article 15 (8); "Of Human Traditions in the Church," §18, BSLK, 300; cf. footnote 37. "Now, it is manifest that the Roman pontiffs, with their adherents, defend [and practice] godless doctrines and godless services. And the marks [all the vices] of Antichrist plainly agree with the kingdom of the Pope and his adherents" ("Constat autem Romanos pontifices cum suis membris defendere impiam doctrinam et impios cultus. Ac plane notae Antichristi competent in regnum papae et sua membra") - Treatise on Power and Primacy of the Pope, $\S 39$, BSLK 484; "This being the case, all Christians ought most diligently to beware of becoming partakers of the godless doctrine, blasphemies, and unjust cruelties of the Pope; but ought to desert and execrate the Pope with his members, or adherents, as the kingdom of Antichrist, just as Christ has commanded (Matt. 7: 15): 'Beware of false prophets' ("Et post aliqua: Quae cum ita se habeant, omnes Christiani quam diligentissime sibi caveant, ne impiae illius (pontificiae) doctrinae, blasphemiarum, tyrannidis crudelissimae participes sese faciant. Pontificem autem, membra et squamas eius ut regnum ipsissimi Antichristi aversentur atque exsecrentur Christus enim id praecepit dicens: Cavete a pseudoprophetis") - Formula Concordiae, Solida Declaratio, Testimonia e Smalcaldicis Articulis, Article 10, § 22, BSLK 1061.

${ }^{58}$ In aller Ewigkeit verdammt? 32.

59 "What happened in the past cannot be changed, but what is remembered of the past and how it is remembered can, with the passage of time, indeed change ... the point is not to tell a different history, but to tell that history differently." 
on January 3, 2021 for the 500th anniversary of the excommunication of Martin Luther, with a special foreword, written by LWF General Secretary Martin Junge and Cardinal Kurt Koch." ${ }^{60}$ The letter ends with a statement that each region has a particular focus, and lives out the ecumenical identity of the Lutheran confessions in different and unique ways. ${ }^{61}$

I notice that Musa expressed his gratitude for the many good initiatives towards reconciliation, but made no further concrete commitments. He did not (and in my opinion could not) comply with the request to delete the relevant passages from the Lutheran confessions, because LWF - as an umbrella organization - is not authorized to do so. That the Lutheran condemnation of the Pope as "Antichrist" does not apply to the present papacy and its ministers is also implicitly stated in JDDJ, §41, and is already stated many times by different Lutheran and Calvinistic churches.

3. The conflicts between Luther and the Pope took place mostly in Germany and this influences the ecumenical climate in Germany to the present day. The AERT asked also the German Bishop's Conference (in consultation with the Central Committee of German Catholics) and the EKD to provide together a joint public statement regretting the events of the past and hoping that the mutual condemnations, which led to the separation between the churches, will be overturned. ${ }^{62}$ An answer came (July 14, 2020) from Bishop Gerhard Feige, chair of the ecumenical commission of the German Bishop's Conference. The letter has been partly published. ${ }^{63}$ The idea of Reconciliation after 500 years fits in well with the current process of Healing of Memories and all the other efforts in service to the unity of the Church, Feige said. I notice that the question asked has not been answered and that no new commitments have yet been made.

4. The AERT addressed the same request to the council and the synod of the EKD. The answer came (June 18, 2020) ${ }^{64}$ This letter refers to many of the aforementioned documents and in particular to Unitatis Redintegratio §3,

\footnotetext{
${ }^{60}$ According to Koch, today's president of PCPCU, Vatican and LWF had "faced the challenge of clarifying, from the ecumenical point of view, the historical, theological, and canonical questions relating to the excommunication of Martin Luther," because "this event continues to represent a painful wound in the history of Catholic-Lutheran division." Koch and Junge reaffirm their commitment to the path from conflict to communion, see https://www.catholicnewsagency.com/ news/vatican-preparing-joint-message-on-martin-luther-with-lutheran-world-federation-38386.

${ }^{61}$ The letter was signed by Dirk G. Lange on behalf of President Musa.

${ }^{62}$ In aller Ewigkeit verdammt? 33.

${ }^{63}$ Ibid., 17.

${ }^{64}$ In aller Ewigkeit verdammt? 15-16. The letter is signed by Hans Langendorfer (SJ) and Thies Gundlach, Secretary of the Vice President of the German Bishop's Conference of the EKD.
} 
saying that today's Christians, who are born outside the Catholic Church, are not guilty of the sin of separation, and the Catholic Church embraces them with respect and affection. All who believe in Christ, and have been truly baptized, are in communion with the Catholic Church even though this communion is imperfect. ${ }^{65}$ The German Bishops Conference and the EKD went through a spiritual reconciliation process in the Reformation Year 2017. They already provided a "common word". ${ }^{66}$ Again, I notice, the question posed has not been answered and no commitment has been made to prepare a joint statement again. It seems as if everything already has been said.

5. Finally, the AERT invited all congregations and local churches to assemble in ecumenical worship (January 3, 2021) for reconciliation. Precisely on that specific day (five centuries ago), Pope Leo X excommunicated Luther. The AERT published a liturgy for it. However, there was hardly any response. The proposal was later supplemented with other possible and obvious dates. ${ }^{67}$

\section{THE BOOK AND ITS CONTENT}

The punishment of excommunication and of eternal damnation (imposed by Pope Leo X) was the reason for the editors to choose a rather provocative title of the book, referring to an American novel by James Jones From here to Eternity (1951), translated in German as Verdammt in alle Ewigkeit. The editors changed its title to In alle Ewigkeit verdammt, adding a question mark. ${ }^{68}$

The main topics are raised and thoroughly elaborated by different disciplines and both denominations. In the twentieth century, we have seen a revision of the Roman Catholic view of Luther. The names of Franz Xaver Kiefl, Sebastian Merkle, Hubert Jedin and especially Josef Lortz should be mentioned here. ${ }^{69}$

\footnotetext{
${ }^{65}$ The document is available at https://www.vatican.va/archive/hist_councils/ii_vatican_council/ documents/vat-ii_decree_19641121_unitatis-redintegratio_en.html.

${ }^{66}$ Erinnerung heilen - Jesus Christus bezeugen. Ein gemeinsames Wort zum Jahr 2017, Gemeinsame Texte 24 (Hannover: DBK, EKD, 2016), available at https://www.dbk-shop.de/de/publikationen/ gemeinsame-texte/erinnerung-heilen-jesus-christus-bezeugen-ein-gemeinsames-wort-jahr-2017.html.

${ }^{67}$ Such as April 18 (Luther at the Diet of Worms), May 24 (Pentecost Monday), June 25 (Memorial day Confessio Augustana), November 17 (Day of Repentance and Prayer).

${ }^{68}$ The book (and its content?) is financially directly or indirectly supported by several German churches and dedicated to Bishop Heinrich Bedford-Strohm, President of the EKD and to Bishop Gerhard Feige, President of the Ecumenical Commission of the German Roman Catholic Bishops' Conference.

${ }^{69}$ Johannes Brosseder, "Luther im Urteil," 109-15. This contribution is a reprint (Brosseder passed away in 2014).
} 
In recent years, many publications have appeared in which the prospects for an ecumenical understanding of the papal office, and also of the so-called apostolic succession, are reconsidered. If we approach the papacy in an ecumenical way, why could not change be possible here too? Even from a Roman Catholic perspective, the question arose whether it would be possible to establish a common body to jointly shape the papacy.

Dorothea Sattler provides in-depth information about a new way of looking at the papal ministry and gives much new literature about it. ${ }^{70}$

The book remembers the historic facts and events during the years 15181520, and the trial against Luther. Not only Luther himself, but also all his followers were excommunicated. According to Hans-Georg Link this means, taken literally, that it affects all today's members of Evangelical-Lutheran Churches. ${ }^{71} \mathrm{He}$ wonders whether church fellowship is conceivable as long as Martin Luther is still officially regarded as a heretic.

Josef Wohlmuth describes the confrontation during the Diet of Worms (1521) between Martin Luther and the Emperor Charles V. Inspired by the Italian philosopher Giorgo Agamben, he quotes the Song of Songs (1:4): fusca sum et decora (I am black and beautiful), following here a theologian of the fourth century, Tyconius, who said that the body of the church consists of two parts: one dark and one beautiful. The church is always simul iusta et peccatrix, polluted and pure at the same time. Therefore, it is not permissible for one denomination to claim, above the others, to be the only true and pure church. ${ }^{72}$

Christian Link, saying that Exsurge Domine is far more interesting than the real Bull of Excommunication (since the content-related questions are discussed here), deals with the threatening bull Exsurge Domine against Luther. He asks if Luther's excommunication can be lifted in the same way as Galileo was rehabilitated under Pope John Paul II (in 1992), incidentally, without an explicit reference to canon law. ${ }^{73}$

Also, interesting is the parallel which Manfred Richter draws with another so-called "heretic", Johannes Hus. He describes how Pope John Paul II, visiting Prague in 1990, expressed his gratitude for the moral integrity of Hus,

\footnotetext{
${ }^{70}$ Dorothea Sattler, "Vom Antichrist zum Zeichen der Einheit. Wandlungen im Verständnis des Petrusdienstes in ökumenischen Kontexten," in Link and Wohlmuth, In alle Ewigkeit verdammt? 124.

${ }^{71}$ Hans-Georg Link, " Der Prozess Martin Luthers von 1518 bis 1520. Eine summarische Übersicht," in Link and Wohlmuth, In alle Ewigkeit verdammt? 48.

72 Josef Wohlmuth, "Der Zusammenprall Martin Luthers, und Kaiser Karls V. auf dem Reichstag zu Worms (1521) und die Folgen bis in die Gegenwart," in Link and Wohlmuth, In alle Ewigkeit verdammt? 164.

${ }^{73}$ Christian Link, 'Die Bannandrohungsbulle 'Exsurge Domine' vom 15. Juni 1520 gegen Martin Luther," in Link and Wohlmuth, In alle Ewigkeit verdammt?" 104.
} 
and he commemorates that one of the teaching philosophers of the John Paul II Catholic University of Lublin, Stefan Swieżawski, raised the question of whether or not Hus should be regarded as a "forerunner of Vatican II" - instead of a "heretic". ${ }^{74}$ Indeed, this was a complete change in perspective.

Gottfried Peters examines the excommunication practice of Catholic canon law, and how it is based on the Bible, especially on Gal. 1:9, on a reinterpretation of the ban practice in the Old Testament, and also as an interpretation of the statements on Matth. 18:17, 1 Cor. 5:1-13, and Titus $3: 10-12$. He thinks it would be desirable if the rejection and banishment statements could be examined again. Service to Unity is after all the leading principle in the Church. ${ }^{75}$

\section{SOME FIRST RESPONSES}

Most responses are friendly and positive, showing their own ecumenical commitment and knowledge. Some voices show indifference or trivialize the importance of it.

The retired German professor Jürgen Ebach completely supports the plea of AERT. He thinks it would be desirable if high-ranking representatives of EKD and LWF took their responsibility now. It is clear that historical facts cannot simply be undone, but the designation of the Pope as Antichrist could and should be off the table. ${ }^{76}$

Johanna Rahner, Roman Catholic professor of dogmatics and ecumenical theology (Tübingen University), fully supports the AERT-appeal. In her eyes, it is high time for an important ecumenical sign to be given. With a symbolic act that abandons the ban to oblivion, the Roman Catholic Church she belongs to could recognize that the theological traditions of the Evangelical Church are also a legitimate inheritance. She is hoping her church will recognize the Lutheran Church as a "Church in the proper sense". ${ }^{77}$ Some passages of the decree

\footnotetext{
${ }^{74}$ Manfred Richter, "Jan Hus und die Versöhnung unserer Erinnerungen,” in Link and Wohlmuth, In alle Ewigkeit verdammt? 70.

${ }^{75}$ Gottfried Peters, “Anathema? Anmerkungen zum 'Petrusdienst' des Paulus in Galatien,” in Link and Wohlmuth, In alle Ewigkeit verdammt? 65.

${ }^{76}$ Jürgen Ebach, "Offener Brief zur Altenberger Erklärung an evangelische Verantwortungsträger," in In alle Ewigkeit verdammt? 184-85.

77 "Mit einer symbolischen Handlung, die den Bann dem Vergessen anheimgibt, könnte die katholische Kirche zum Beispiel anerkennen, dass auch die theologischen Traditionen der evangeli-
} 
Unitatis Redintegratio can be interpreted as a lifting of excommunication, and of course she knows that. Nevertheless, the Bull of Excommunication refers to the content of the doctrines of the Reformer, still alive in today's Protestant churches. Therefore, the withdrawal is still important, in her view.

Andreas Woehle, President of the Evangelical Lutheran Synod in the Protestant Church in the Netherlands, is less enthusiastic. He uses the word "peanuts". By hammering on that one point, we should acknowledge the Pope in his "legal authority" in the church, he stresses. This is precisely what the Reformation rejected. Moreover (referring to the JDDJ), it does not do justice to all the positive things we have already achieved in our dialogue with the Roman Catholic Church. This also applies to the designation "Antichrist". Woehle adds: "We, as Lutherans, will not say that anymore.",78

Bertram Meier, the Roman Catholic bishop of Augsburg, states briefly that with Luther's death, excommunication is extinguished and now there are other more important priorities in ecumenism. ${ }^{79}$

Bernhard Kaiser, Rector of the Institute for Reformed Theology in Reiskirchen, states that the AERT has carefully demonstrated that the conflict in $1520 / 1521$ was essentially about papal claims to power. Luther challenged the authority of the papacy, and, in contrast, emphasised the authority of Scripture and of Christ. Since Luther was driven by theological motives, it would be good if the AERT had a thorough theological discussion, which would also address the issues of human image, church and sacraments. ${ }^{80}$

Dorothea Sattler, professor of ecumenical theology and dogmatics (Münster University), one of the authors of the AERT-book, understands fully the desire for Luther's excommunication to be lifted, as it no longer fits with the current state of ecumenism. Still she shares the idea of Woehle and Bertram that such a formal step is not really necessary. It could give the impression that the Roman Catholic Church claims the authority to judge - beyond death - who is, and who is not accepted by God. Moreover, painful memories cannot be healed through a legal act alone. ${ }^{81}$

schen Kirche ein legitimes Erbe sind, sie also durchaus auch 'Kirche im eigentlichen Sinn' ist"; available at https://www.domradio.de/themen/\%C3\%B6kumene/2021-01-13/ein-wichtiges-zeichentheologin-rahner-fordert-aufhebung-von-kirchenbann-ueber-luther.

${ }^{78}$ Maarten Stolk and Klaas van der Zwaag, "Banvloek Luther opnieuw ter discussie," Reformatorisch Dagblad, January 9, 2021, pp. 10-11.

79 "Bisschop van Augsburg tegen herroeping excommunicatie van Luther," Kerknet, January 5, 2021, https://www.kerknet.be/kerknet-redactie/nieuws/bisschop-van-augsburg-tegen-herroepingexcommunicatie-van-luther.

${ }^{80}$ Stolk and Zwaag, "Banvloek Luther opnieuw ter discussie," 10-11.

${ }^{81} \mathrm{https}$ //www.herder.de/cig/cig-ausgaben/archiv/2021/2-2021/stichwort-der-bann-gegen-luther/n. 
Ralf Meister (EKD), Bishop of Hanover, called on the churches finally to put their confessional differences aside in favour of closer cooperation in an increasingly secular society. Only in ecumenical solidarity, the church will remain recognizable. Without strong ecumenical efforts, the voice of Christianity will become significantly weaker. In our time, the question of denominations is not important any more, he says. The question is whether or not one believes at all.

Bishop Karl-Hinrich Manzke, the Catholica representative of the United Evangelical Lutheran Church of Germany (VELKD) makes all ecumenical flowers bloom. In his foreword to In alle Ewigkeit verdammt? (pp. 12-14), he points out the importance of all well-known ecumenical documents and activities. He specifically mentions the Focolare Movement and the Community of Saint Egidio. It is clear that Christian witness gains in persuasiveness, leaving the divisions of the past behind, when it is in reconciled diversity. According to AERT, now is the time for a self-critical public speaking from the Roman Catholic Church regarding the excommunication of Luther and all of his followers. It is also time for a self-critical "Public Word" from the Protestant side condemning the papacy as Antichrist in their confessional writings.

\section{THE GOOD NEWS}

Already at the beginning of 2020, LWF and PCPCU announced a joint commemoration event for the 500th anniversary of Luther's excommunication on January 3, 1521. Accordingly, they prepared a joint ecumenical liturgical event in Rome (June 25, 2021) in anticipation of the 500th anniversary of the Confessio Augustana, which was presented in $1530 .{ }^{82}$

\section{CONCLUSION}

Nobody wants to enter into fellowship with a "heretic" and an "Antichrist." Therefore, these mutual convictions must be eliminated. The AERT has made an important contribution to the ecumenical discussion and has approached the leaders of the Roman Catholic and Lutheran Churches on

82 "Remembering history with an openness to the future," The Lutheran World Federation, January 24, 2020, https://www.lutheranworld.org/news/remembering-history-openness-future. 
a national and international level with the request to undo the anathemas from the past. Other parts of the protestant family (WARC, the Anglican Communion, the World Methodist Council and many other Reformed and Presbyterian Churches) have not been approached. That could be done as well, and it could be the next step. For churches not belonging to a world church, spread over many denominations, it will be more difficult to discover what has to be revoked and by whom, but in these pages I have given some examples. Some voices ask if it is really necessary to dig so deeply into history as AERT does, but I am grateful for it. We have heard voices saying that an official legal act of the Pope is not necessary. It would give the papacy an authority it does not have, and the consequences are unclear. We noticed that the Protestant Confessions of the sixteenth century cannot be changed, at best concealed. In my opinion the Altenberg Plea is still an important movement to bring forward the ecumenical vision of unity in reconciled diversity, awaiting that moment when all Christians will be able to celebrate together the Lord's Supper. The time will come when no denomination will presume that other churches must adhere to the so-called "ecclesiastical communities", and not be the Church in the proper sense..$^{83} \mathrm{I}$ am well aware that there are still major theological differences between Roman Catholics and Protestants: for example the vision of the church, the papacy, the sacraments, and ministry. All do not embrace even JDDJ. With Luther's rehabilitation, these stumbling blocks are not brushed away. There is willingness on both sides, and many important steps have already been taken, but there is still a long way to go.

${ }^{83}$ In Dominus Iesus it was made clear that Lumen Gentium $\S 8$ is interpreted restrictively. Protestants are still not real churches, just "ecclesiastical communities". Cf. Margriet Gosker, "Wer dafür eine Nase hat...," 220; Joseph Ratzinger, Dominus Iesus, Verklaring over de uniciteit en heilbrengende universaliteit van Jezus Christus en de Kerk, 2000 (available at https://www.rkdocumenten.nl/ rkdocs/index.php?mi=600\&doc=78. Lumen Gentium $\$ 8$ explains that outside of the Roman Catholic Church there are several elements of sanctification and truth in churches and "ecclesial communities" with which the Roman Catholic Church has not yet full communion: "Haec Ecclesia ... subsistit in Ecclesia Catholica, a successore Petri et Episcopis in eius communione gubernata, licet extra eius campaginem elementa plura sanctificationis et veritatis inveniantur" (Denzinger, Hünermann, 4119). The interpretation of those who deduce from the formula 'subsistit in' that the one Church of Christ also includes non-Catholic churches and ecclesial communities is in contradiction to the authentic significance of Lumen Gentium (Dominus Iesus, 2000, chap. 4, footnote 56 in the German version). 


\section{BIBLIOGRAPHY}

Altenberger Erklärung, "Versöhnung nach 500 Jahren. Plädoyer für die Außerkraftsetzung der Bannbulle Papst Leos X. gegen Martin Luther samt all seinen Anhängern und für die Rücknahme des reformatorischen Verdikts gegen den Papst als 'Antichrist'." In In alle Ewigkeit verdammt? Zum Konflikt zwischen Luther und Papst nach 500 Jahren. Eine Stellungnahme des Altenberger Ökumenischen Gesprächskreises. Edited by Hans-Georg Link and Josef Wohlmuth, 30-33. Göttingen: Grünewald/Vandenhoeck \& Ruprecht, 2020.

"Bisschop Bätzing: 'Synodale Weg' vervolgen in dialoog met Rome.” KN, January 5, 2021. https:// www.kn.nl/duitsland/bisschop-batzing-synodale-weg-vervolgen-in-dialoog-met-rome.

"Bischof Wilmer begrüßt Vorschlag zu 'ökumenischen Gemeinden'.” Katholisch, January 3, 2020. https://www.katholisch.de/artikel/24094-bischof-wilmer-begruesst-vorschlag-zu-oekumenischengemeinden.

"Bisschop van Augsburg tegen herroeping excommunicatie van Luther." Kerknet, January 5, 2021, https:/www.kerknet.be/kerknet-redactie/nieuws/bisschop-van-augsburg-tegen-herroepingexcommunicatie-van-luther.

Brosseder, Johannes. "Luther im Urteil der gegenwärtigen katholischen Theologie.“ In Link and Wohlmuth, In alle Ewigkeit verdammt? 108-15.

Calvijn, Johannes. Het gepredikte woord. Vol. 3, Preken van Johannes Calvijn vertaald door J. Douma en W.H. v.d. Vegt. Part 5, Preken over de kerk. Franeker: Wever, 1978.

Calvijn, Johannes. Institutie of onderwijzing in den christelijken godsdienst, uit het Latijn vertaald door A. Sizoo. Derde deel, bevattende boek IV. Delft: Meinema, s.d., [1931].

Die Bekenntnisschriften Der Evangelisch-Lutherischen Kirche. Herausgegeben im Gedenkjahr der Augsburger Konfession 1930. Göttingen: Vandenhoeck \& Ruprecht, 1998.

Ebach, Jürgen. "Offener Brief zur Altenberger Erklärung an evangelische Verantwortungsträger." In Link and Wohlmut, In alle Ewigkeit verdammt?, 184-185.

Erinnerung heilen - Jesus Christus bezeugen. Ein gemeinsames Wort zum Jahr 2017. Gemeinsame Texte 24. Hannover: DBK, EKD, 2016.

From Conflict to Communion: Lutheran-Catholic Common Commemoration of the Reformation in 2017. Leipzig: Evangelische Verlagsanstalt-Bonifatius, 2013.

"Gereformeerden zien mis niet langer als afgoderij." Trouw, July 21, 2005. https://www.trouw.n1/ nieuws/gereformeerden-zien-mis-niet-langer-als-146-afgoderij-146 b92182fa.

Gosker, Margriet. Het kerkelijk ambt in het Limadocument. Een hermeneutische doorlichting en een kritische evaluatie van de Lima-Ambts-tekst. Utrecht/Leiden: IIMO Research Publication 29, 1990.

Gosker, Margriet, ed. A Man for All Seasons. Essays in recognition of work of Richard van Houten for the Reformed Ecumenical Council 1987-2010. Grand Rapids: Reformed Ecumenical Council, 2010.

Gosker, Margriet. 'Gods 'ja' en het 'nee' van de kerk. Ambtstheologische notities bij de vrouw in het ambt." In Honderd jaar vrouwen op de kansel, 1911-2011, edited by Mirjam de Baar, Frederike Cossee, and Mirjam van Veen en Anna Voolstra, 53-65. Hilversum: Verloren, 2011.

Gosker, Margriet. "Wer dafür eine Nase hat... Das Lima-Dokument 30 Jahre später - Fokus: Die Niederlande." Una Sancta 67(2012), 3: 216-25.

Gosker, Margriet. "500 Jahre Protestantismus in den Niederlanden.” In Zeit der Versöhnung, Wege in die Zukunft der Ökumene, edited by Hans-Georg Link and Dorothea Sattler, 88-93. Vandenhoek \& Ruprecht, 2017. 
Gosker, Margriet. "Eros vár a mi istenünk.” Sárospataki Füzetek 21(2017), 2: 29-44.

Gosker, Margriet. "Samen op weg - Gaandeweg één. 500 jaar Reformatie en Oecumene.” Perspectief, Internettijdschrift van de Katholieke Vereniging voor Oecumene, April 3, 2017.

Gosker, Margriet. "Maria 2.0”. Mariënburg Magazine 37(2020), 5: 14-16.

Houtepen, Anton. Anatomie van het anathema. Over uitsluiting en verzoening, Verdeeldheid en hereniging in het oecumenisch proces. Utrechtse theologische reeks 48. Utrecht: Universiteit Utrecht, 2004.

Lehmann, Karl, and Wolfhart Pannenberg. Lehrverurteilungen - kirchentrennend? Vol. 1. Rechtfertigung, Sakramente und Amt im Zeitalter der Reformation und heute. Freiburg im Breisgau: Herder/Vandenhoeck \& Ruprecht, 1986.

Leppin, Volker, and Dorothea Sattler, eds. Gemeinsam am Tisch des Herrn, Ein Votum des Ökumenischen Arbeitskreises evangelischer und katholischer Theologen. Freiburg im Breisgau: Herder; Göttingen: Vandenhoeck \& Ruprecht, 2020.

Link, Christian. "Die Bannandrohungsbulle 'Exsurge Domine' vom 15. Juni 1520 gegen Martin Luther." In Link and Wohlmuth In alle Ewigkeit verdammt?, 94-107.

Link, Hans-Georg, and Josef Wohlmuth, eds. In alle Ewigkeit verdammt? Zum Konflikt zwischen Luther und Papst nach 500 Jahren. Eine Stellungnahme des Altenberger Ökumenischen Gesprächskreises. Göttingen: Vandenhoeck \& Ruprecht; Ostfildern: Grünewald, 2020.

Link, Hans-Georg, Inge Keidel, and Rudolf Weth, eds. Dokumentation der Wittenberger Ökumenischen Versammlung. Köln: private printing, 2018.

Link, Hans-Georg, "Der Prozess Martin Luthers von 1518 bis 1520. Eine summarische Übersicht." In Link and Wohlmuth, In alle Ewigkeit verdammt?, 36-48.

Link, Hans-Georg, "Vom 'Antichrist' zum 'Bruder in Christus'. Zur Aufarbeitung des reformatorischen Antichrist-Verdikts gegen das Papsttum.” In Link and Wohlmuth, In alle Ewigkeit verdammt?, 127-147.

Lutheran-Roman Catholic Commission on Unity. "Martin Luther - Witness to Jesus Christ." christianunity.va. http://www.christianunity.va/content/unitacristiani/en/dialoghi/sezione-occidentale/ luterani/dialogo/documenti-di-dialogo/en13.html.

Manzke, Karl-Hinrich. "Geleitwort der Catholica-Beauftragte der Vereinigten EvangelischLutherischen Kirche Deutschlands." In Link and Wohlmuth, In alle Ewigkeit verdammt? 12-14.

Moehn, Wim H.Th. "Mis als 'vervloekte afgoderij' verraadt context van Trente." Protestants Nederland 85, no. 3 (2021): 64-67.

Müller, Ernst Friedrich Karl, ed. Die Bekenntnisschriften der reformierten Kirche. In authentischen Texten mit geschichtlicher Einleitung und Register. Theologische Studien - Texte 5.2 [Nachdruck der Ausgabe Leipzig, 1903]. Waltrop: Spenner, 1999.

Noll, Mark A. and Carolyn Nystrom. Is the Reformation Over? An Evangelical Assessment of Contemporary Roman Catholicism. Grand Rapids: Baker Academic Publishing Group, 2005.

Peters, Gottfried. "Anathema? Anmerkungen zum 'Petrusdienst' des Paulus in Galatien." In Link and Wohlmuth, In alle Ewigkeit verdammt? 49-65.

"Protestanten nennen 2030 als Zielmarke für ökumenischen Durchbruch." EKD, November 11, 2017, https://www.ekd.de/protestanten-nennen-2030-als-zielmarke-fuer-oekumene-30500.htm.

Radano, John A. Lutheran and Catholic Reconciliation on Justification: A Chronology of The Holy See's Contributions, 1961-1999, to a New Relationship between Lutherans and to Steps leading to the Declaration on the Doctrine of Justification. Grand Rapids: William B. Eerdmans, 2009. 
"Remembering history with an openness to the future." The Lutheran World Federation, January 24, 2020, https:/www.lutheranworld.org/news/remembering-history-openness-future.

Rex, Richard. The making of Martin Luther. Princeton: Princeton University Press, 2017.

Richter, Manfred. "Jan Hus und die Versöhnung unserer Erinnerungen." In Link and Wohlmuth, In alle Ewigkeit verdammt? 66-93.

Sander, Augustinus. "Pater Sander: 'Wir müssen über den eigenen Kirchturm hinausschauen'." Vatican News, January 5, 2021. https://www.vaticannews.va/de/vatikan/news/2021-01/vatikanoekumene-pater-sander-itv-geleitwort-rechtfertigung-text.html.

Sattler, Dorothea. "Vom Antichrist zum Zeichen der Einheit. Wandlungen im Verständnis des Petrusdienstes in ökumenischen Kontexten." In Link and Wohlmuth, In alle Ewigkeit verdammt?, 116-126.

Schelkens, Karim. "Re-Interpreting Historical Dividedness. The Hierarchy of Councils as A Means for Christian Unity." In The Normativity of History: Theological Truth and Tradition in the Tension between Church History and Systematic Theology, edited by Lieven Boeve, Mathijs Lamberigts, and Terrence Merrigan, 67-99. Leuven: Peeters Publishers, 2016.

Schelkens, Karim. Johannes Willebrands. Een leven in gesprek. Amsterdam: Boom Uitgevers, 2020.

Stolk, Maarten, and Klaas Van Der Zwaag. "Banvloek Luther opnieuw ter discussie." Reformatorisch Dagblad, January 9, 2021, 10-11.

Willebrands, Jean. Lettre du cardinal Willebrands à M. Rudolf Knecht, président de la Commission décanale catholique de Worms. La Documentation Catholique. 54, 1600, 2.1.(1972), 32-33 (lettre datée du 14.7.1971).

Wohlmuth, Josef. "Der Zusammenprall Martin Luthers und Kaiser Karls V. auf dem Reichstag zu Worms (1521) und die Folgen bis in die Gegenwart." In Link and Wohlmuth, In alle Ewigkeit verdammt? 148-65.

Zitting, Heidi. The Episcopal Office in transition. Finnish Lutheranism and the Lutheran World Federation Discussions on Episkope 1945-2015. Helsinki: Faculty of Theology, 2020.

Zwanepol, Klaas. Belijdenisgeschriften voor de Protestantse Kerk in Nederland. Zoetermeer: Boekencentrum, 2004.

\section{CZY EKSKOMUNIKA NA LUTRA ZOSTANIE ZNIESIONA W 2021 ROKU? APEL EKUMENICZNEGO OKRĄGŁEGO STOŁU Z ALTENBERGU}

$$
\text { Streszcze ni e }
$$

Altenberskie ekumeniczne obrady okrągłego stołu w swej deklaracji odwołują się do papieża Franciszka, pytając się go o zniesienie ekskomuniki na Marcina Lutra i jego następców, apelując jednocześnie do Światowej Federacji Luterańskiej o usunięcie z wyznań wiary ustępów określających papieża jako Antychrysta. W artykule zostaje opisana działalność grupy: publikacja tzw. Apelu Altenberskiego i publikacja książki dotyczącej tematu, z uwzględnieniem jego podstaw, jak i pierwszych reakcji. Ponadto zaprezentowane zostaje stanowisko autorki.

Słowa kluczowe: Apel altenberski; ekumenizm; Luter; ekskomunika, wspólna deklaracja; Wyznanie Augsburskie. 